\title{
'Wir tun nichts Gutes, wobei wir nicht sündigen': De heiliging in de verkondiging binnen de gereformeerde kerk in het 19e eeuwse Wuppertal
}

\author{
Author: \\ J. Hans Kommers ${ }^{1,2}$ \\ Affiliations: \\ ${ }^{1}$ Faculty of Theology, \\ North-West University, \\ Potchefstroom Campus, \\ South Africa \\ ${ }^{2}$ Faculty of Theology, VU, \\ Amsterdam, The Netherlands. \\ Correspondence to: \\ Hans Kommers \\ Email: \\ j.kommers777@gmail.com \\ Postal Address: \\ Operadreef 94, 3845GR \\ Harderwijk, the Netherlands \\ Dates: \\ Received: 23 Feb. 2011 \\ Accepted: 06 June 2011 \\ Published: 31 Oct. 2012 \\ How to cite this article: \\ Kommers, J.H., 2012, "“Wir \\ tun nichts Gutes, wobei wir \\ nicht sündigen": De heiliging \\ in de verkondiging binnen de \\ gereformeerde kerk in het 19 \\ eeuwse', In die Skriflig/In Luce \\ Verbi 46(1), Art. \#48, 9 pages. \\ http://dx.doi.org/10.4102/ids. \\ v46i1.48 \\ Note: \\ Dr. J. Kommers was a pastor \\ for 35 years in the Netherlands \\ Reformed Church, of which \\ many years were spent on \\ the mission field in Kenya \\ and Moçambique. In 2005 he \\ received his $\mathrm{PhD}$ at the North- \\ West University (NWU) in \\ Potchefstroom. His promotor \\ was Prof. J.M. Vorster. Dr. \\ Kommers is currently living in \\ the Netherlands and works as \\ a researcher at the Theological \\ Faculty of the NWU. He is \\ also affiliated with the VU \\ Amsterdam, with the IRTI \\ project of the Theological \\ Faculty and is a member \\ of PROMISE (Foundation \\ for Promotion of reformed \\ Missiology and Eucumenics). \\ C 2012. The Authors \\ Licensee: AOSIS \\ OpenJournals. This work \\ is licensed under the \\ Creative Commons \\ Attribution License.
}

In de turbulente jaren van het midden van de 19e eeuw opponeerde de prediker Hermann Friedrich Kohlbrügge (1803-1875) tegen het optimistische vooruitgangsgeloof van zijn tijd, met zijn reformatorische verkondiging waarin Jezus Christus in het midden van de verkondiging werd gezet. In zijn preken schilderde hij niet met waterverf; een natte spons erover en alles was weg, maar zijn woorden haakten in harten en gewetens van zijn toehoorders. Juist op het 'doen' in het geloof legde hij accenten, waar tot op deze dag nog over gesproken wordt. Hoe zit het? Een christen doet goede werken en is volkomen in Christus en dan toch: 'Wir tun nichts Gutes, wobei wir nicht sündigen.' De concrete, praktische zaken van het leven worden bij hem niet geplaatst in de ervaringswereld van de toehoorders, kortom, dichter bij hun leven, maar toehoorders en hun werkelijkheid worden gezien in het licht van de opgestane Christus. Hoe voorkomen wij dat ons kader wordt scheefgetrokken waarin het menselijke en het geestelijke gescheiden wordt? Heiliging vraagt om een geïntergreerd leven.

'Wir tun nichts Gutes, wobei wir nicht sündigen': The sanctification in the ministry within the Reformed church in the 19th century Wuppertal. In the turbulent years of the mid-19th century the preacher Hermann Friedrich Kohlbrügge (1803-1875) stood up against the prevailing opinion of an optimistic feel good religion with a biblical preaching in which Jesus Christ is glorified. When he preached, he did not portray with a pencil, which can be erased easily. His words were engraved in the hearts and conscience of the people listening to him. His way of highlighting the 'deeds' in Christian belief, are issues people still discuss today. This is how he sees it: a Christian does good deeds and is completely sanctified in Christ, yet 'Wir tun nichts Gutes, wobei wir nicht sündigen' (Kohlbrügge 1903:33). The practical and modern day issues of life are not placed in the experienced way people were used too, but the reality is being shown in the light of the Risen Lord. How do we prevent our framework from being pulled into the wrong direction? A direction in which the human and spiritual is separated. Sanctification means an integrated life.

\section{Inleiding}

De irreguliere theoloog Kohlbrügge baarde in de 19e eeuw in de grote industriestad Wuppertal groot opzien door zijn verkondiging. De ernst van de zonde en de radicaliteit van de genade werd door hem benadrukt. Ook de bekeerde mens is vlees en vindt zijn heiligheid enkel in Christus. Het volgens hem werkheilig getint activisme binnen de kring van het Réveil, moest het ook ontgelden. De vraag hier aan de orde is op welke wijze de heiliging in deze streng christologische preken aan de orde kwam. Welke bouwstenen bood deze sterk exegetisch gestempelde Schriftuitleg voor de ethiek en het ethisch handelen van de gelovigen?

\section{Prediking als een gebeuren}

Wie de rijk gevulde werkzame jaren in kerk, theologie en academie van Koos Vorster overziet, zal het niet ontgaan dat daarin de ethiek een grote plaats inneemt. Op de verantwoordelijkheid van de christen in het openbare leven heeft hij in woord en geschrift zijn licht laten schijnen. In dankbaarheid voor wat God ons in hem geschonken heeft zijn de volgende regels waarin aandacht wordt gevraagd voor de heiliging in het leven van de christen, aan hem gewijd.

De heiliging zoals die in de verkondiging aan de orde komt is een aanlokkelijk thema, omdat het in de Bijbel zo heel belangrijk is en de plaats van de christen in de samenleving aangeeft, maar het is ook een complex thema omdat door de eeuwen heen, dit op een zeer verschillende manier is behandeld. Wij concentreren ons op de prediking en kerkelijke situatie in de eerste decennia van de 19e eeuw in het Wuppertal (Duitsland), waar binnen de kerkelijke gemeenten een opwekking plaatsvond. 
Wat gebeurt er wanneer God door Zijn Woord mensen in Zijn helende werkzaamheid betrekt? Getuigenissen van mensen uit ons gekozen tijdvak laten zien dat deze preken verandering van het hart veroorzaakten. Het waren geen preken over God, over een tekst en over een gemeente, maar het was verkondiging in het Bijbelwoord, in het handelen van God. Er werd niet gesproken over de troost, maar deze preken troostten!

\section{'Auferstehungszeit'}

De eerste decennia van de 19e eeuw, waarin na de Franse overheersing een nieuw élan doorbrak op kerkelijk, maatschappelijk en economisch gebied, werd door Friedrich August Tholuck (1799-1877), getypeerd als 'Auferstehungszeit' [Opstandingstijd] (Tholuck 1823).

Binnen de Rijnprovincie van het koninkrijk Pruissen was het Wuppertal sinds het begin van de 19e eeuw een bijzonder levendig centrum van de opwekkingsbeweging (zie Benrath 2000); het 'Kanaän van het Westen' (ibid.). ${ }^{1}$ De beide gereformeerde Krummachers, Gottfried Daniël (1774-1837) in Elberfeld en zijn neef Friedrich Wilhelm (1796-1868) in Gemarke (Barmen), stimuleerden de ontstane opwekkingsgolven. De van oorsprong lutherse, later calvinistische prediker Hermann Friedrich Kohlbrügge ging in die tijd zijn eigen weg in Elberfeld; theologisch accordeerde hij het meest met G.D. Krummacher (zie Schütz 1972). ${ }^{2}$

Deze predikers verbonden luthers en calvinistisch erfgoed en zetten zich in voor een herbeleving van de reformatorische theologie. G.D. Krummacher heeft de piëtistische erfenis in reformatorische zin verdiept (Krummacher 1935), en Kohlbrügge heeft 'Kräftiger als irgend einer vor ihm und nach ihm im 19. Jahrhundert die Reformations Theologie wieder auf den Plan geführt' [Krachtiger dan wie ook voor hem en na hem in de 19e eeuw de Reformatie Theologie weer op de kaart gezet] (Barth 1981:585). Naast deze drie gereformeerden was de lutherse prediker A. Döring (1783-1844) van grote invloed binnen de opwekkingsbeweging. In de verkondiging ging het om het heil van de enkeling, cirkelend om de vragen van zonde en genade.

Een ander geluid liet de theoloog A. Bräm (1797-1882), uit Neukirchen, horen. Hij riep op tot het heil in Christus, waarbij hij niet naliet in de verkondiging te benadrukken, dat in het gewone, alledaagse leven, thuis en in de fabriek de sociale consequenties van het geloof gezien zouden worden. Hij redigeerde het blad Die Biene, met daarin artikelen over de sociale thema's van die tijd, onder andere over de grote nood onder de eenvoudige wevers, de misstanden onder de fabrieksarbeiders, de armoede, et cetera en daarbij geeft Bräm

\footnotetext{
1.In 1825 schrijft een correspondent van het Elberfelder Partikulargesellschaft naar Bazel: 'Kurz, wir haben jetzt ein Land Gosen, ein rechtes Canaan hier und in hiesiger Gegend in der Runde von zwei oder drei Stunden. Denken sie sich 20 erleuchtete, Gegend in der Runde von zwei oder drei Stunden. Denken sie sich 20 erleuchtete,
wiedergebohrene Prediger'. 186. Hier worden dan aangehaald predikers als G.D en Fr.W. Krummacher; J. Wichelhaus; K.A. Döring; J.W. Leipolt; I.F. Sander e.a.
}

2.W. Schütz (1972:192) noemt Kohlbrügge 'Ein theologisch eigengeprägter und tiefschürfender Vertreter der reformierten Predigt'. ook pedagogische adviezen ${ }^{3}$ (Lohbeck 1989). De arbeiders in die tijd, ook de kinderen, werden aangeduid als ' produzierende Masse' [producerende massa] (Lohbeck 1989:205, 207).

Het Wuppertal, met de zustersteden Elberfeld en Barmen als centrum, kreeg tussen 1840 en 1875 door de textielindustrie een wereldnaam. De bevolking in het Wuppertal nam zo snel toe, dat de steden de groei niet meer konden reguleren. Woon- en leefomstandigheden voor de fabrieksarbeiders waren erbarmelijk. Dit raakte ook de kerkleden. Een klein aantal leden van de kerk was fabrikant en zeer bemiddeld, maar het merendeel van de parochianen bestond uit arme wevers. Velen leefden in troosteloze woningblokken van de stad, zelfs in lemen hutten. De scherpe tegenstellingen tussen de bezittende en sociaal leidende kringen en het groeiende leger van arbeiders werden steeds groter. Er was de dagelijkse strijd om te overleven, waarbij heel veel kinderen van vijf tot dertien jaar soms elke dag vijftien uur (!) ononderbroken in de fabriek moesten werken, waar ze 'geestelijk en lichamelijk te gronde werden gericht'(zie Kommers 2005:59-70).

Friedrich Engels (1820-1895), zoon van een fabrikant uit Barmen en groot geworden in een piëtistisch milieu, geeft een bijtend oordeel over de situatie in Elberfeld:

Aber es herrscht ein schreckliches Elend unter den niedern Klassen, besonders den Fabrikarbeitern im Wupperthal [...]. Denn das ist ausgemacht, dass unter den Fabrikanten die Pietisten am schlechtesten mit ihren Arbeitern umgehen, ihnen den Lohn auf alle mögliche Weise verringern. [Maar er bestaat een verschrikkelijke ellende onder de laagste klassen, in het bijzonder de fabrieksarbeiders in het Wuppertal. [...] Want het is zeker dat onder de fabrikanten, de pietisten het slechtst met hun arbeiders omgaan (en) hen het loon op allerlei manieren korten.] (auteur eigen vertaling) ${ }^{4}$

Engels heeft samen met Karl Marx het Communistisch Manifest opgesteld.

In het gereformeerde en lutherse Wuppertal, met een duidelijke piëtistische spiritualiteit, ontstond naast een bijbelvaste gemeente een grote groep fabrieksarbeiders die de kerk de rug toe keerden en hun heil zochten in de communistische leer. De vraag die wij niet kunnen ontwijken is: Hebben de predikanten de sociale noden opgemerkt en in de prediking vertolkt? Is de stem van de opwekkingsprediker Ludwig Harms (1808-1865) gehoord toen hij zei: 'Die Zeitumstände unberücksichtigt lassen ist eine unfruchtbare Abstraktion' [Het niet bezien van de omstandigheden der tijd is een onvruchtbare abstraktie] (zie Grafe 1965:159).

Wij willen nagaan op welke wijze de predikanten de sociale vragen en maatschappelijke noden in hun prediking hebben meegenomen of dat zij deze buiten de deur hielden, c.q. kwam de heiliging aan de orde in de verkondiging? Was voor hen de heiliging een theologische kwestie of beoogden ze ook een toepassing voor het alledaagse leven?

3.Bräm was in 1846 de oprichter van Der Verein für Familienerziehung armer und verwahrloster Kinder Zie over hem E. Lohbeck, Andreas Bräm - ein Wegbereiter verwahrloster Kinder. Zie over hem E. Lohbeck, Andreas Bräm - ein Wegbereiter der Diakonie im Rheinland und Gründer des Neukirchener Eraiehungsvereins, SVRK, 94, Neukirchen-Vluyn, 1989. Het hierboven gestelde op pagina 119 en 112. 'Die Biene möchte Zeugnis geben von etwas, davon man sonst weniger hört und liess und was dir, so lange du auf Erden bist, auch nötig ist, namlich was du in Gottes nemen und nach seinem Wort mit dem auswendigen machen sollst'. A.w.:114.

4.In MEGA I, 3, S.35. 
Het oorspronkelijke piëtisme wilde niet in onjuiste moralisering vervallen, en men wist van de ethische consequentie van het evangelie voor de sociaal armen en ellendigen. En in het 19e eeuwse Wuppertal? Werkte de verkondiging alomvattend; niet alleen voor de ziel, maar ook voor de concrete mens?

\section{'Alles is kerk en handel'}

In 1838 schrijft de hoogleraar Karl I. Nitzsch uit Bonn: 'Alles ist Kirche und Handel, Mission und Eisenbahn, Bibel und Dampfmaschine; nach Kunst und Wissenschaft fragt man wenig oder gar nicht, kaum nach Politik' [Alles is kerk en handel, missie en spoorwegen, Bijbel en stoommachine; naar de kunst en wetenschap vraagt $u$ weinig of niet, ( $u$ vraagt) nauwelijks naar politiek] (Herberts z.j:3). Het Wuppertal in de 19e eeuw was niet alleen het centrum van de opwekkingsbeweging ${ }^{5}$ (Zie Gäbler 1991:162; Beyreuther 1980:365), maar ook van de beginnende industrialisering en van scherpe klassentegenstellingen. Wij zien dat in de 19e eeuw in het Wuppertal praktisch binnen één generatie zich de sprong voltrok van een agrarische staat naar een industriële natie (zie Greshat 1980:155-160, 208-231). In 1875 was van de 81000 inwoners van Elberfeld ruim 25\% werkzaam in de industrie. In 1841 kwam de eerste trein met stoomaandrijving op het traject Elberfeld - Düsseldorf. In de jaren veertig van de 19e eeuw komt West-Europa in de greep van een economische crisis. Veel mensen in Elberfeld, vooral de wevers verliezen hun baan en leven onder erbarmelijke omstandigheden. Een revolutiegeest vanuit Parijs, waait in februari 1848 over geheel West-Europa.

De voorbereidingen van de revolutie van 1848, de groeiende onvrede van de arbeidersklasse; dit alles heeft de kerk overvallen. ${ }^{6}$ Het antwoord van de kerken kwam, hoewel wat laat, in de vorm van diakonale projecten. Bekend is het 'Elberfelder System'; een van oorsprong diakonaal projekt van de Niederländisch Reformierte Gemeinde, de gemeente van Kohlbrügge. Dit projekt werkte zo goed dat het model werd voor heel burgerlijk Elberfeld en daarna voor heel Duitsland (zie Kommers 2005:70-72).

In de tijd van de opkomende industrialisering keerden de meeste fabrieksarbeiders zich af van het kerkelijke leven. Vanaf 1829 maakte Elberfeld kennis met stakingen en arbeidsonlusten. De klassenstrijd brak nu volledig door. Socialisme en materialisme maakten zich van grote lagen van de bevolking meester. Wij zien dat in hogere kringen pas vanaf 1870 een andere levensinstelling merkbaar wordt.

5.De opwekkingsbeweging moeten wij zien als een 'elementaire boetebeweging' die door de prediking het volk tot het eenvoudige Bijbelse geloof wil terugvoeren en zodoende de reformatorische doelstellingen opnieuw te laten gelden. Tot Christus komen betekent tot de Bijbel komen. In de opwekkingsbeweging staat de ervaring van de gelijktijdigheid van de Bijbel op de voorgrond. Johannes 7:17 is hier leidend.

6.Dit is de teneur van de studie van J. Hermand Der Deutsche Vormärz. Texte und Dokumente, Stuttgart, 1967. Zo ook in J. Kuccynski Das Entstehen der Arbeitersklasse, München, 1967. Lothar Przybylski vermeldt dat het Wuppertal en zelfs geheel Duitsland 'plötzlich und ungeschützt von den revolutionären Tendenzen der Zeit überfallen war', in Die Kirche am Kolk, Die Geschichte der evangelisch-lutherischen Gemeinde Elberfeld, Brockhaus Verlag, Wuppertal, 1977:74.
Dan is van een puriteinse levenswijze in het Wuppertal nauwelijks sprake meer. ${ }^{7}$

\section{Geestelijke situatie}

De heiliging was het hoofdthema van het latere Calvinisme, van Puritanisme, van Piëtisme. Dit is al te zien aan de liederen uit die tijd. Hier wordt bijna overal - op basis van geloof en rechtvaardiging - gezocht en gestreefd naar een hogere zelfkennis, zelfbeproeving en ervaringen van Gods nabijheid. Om de geestelijke situatie van die tijd te beoordelen op het punt van de heiliging kunnen wij niet om H.F. Kohlbrügge heen. Deze 'Wiedererwecker reformatorische Verkündigung' [Wederopwekker van de reformatorische verkondiging] (Kreck 1982:234) heeft tot vandaag een stem in kerk en theologie. In zijn prediking is de heiliging zeer aanwezig. Alleen de antwoorden die hij geeft op de heiligingsvragen zijn anders dan die van de religieuze wereld van zijn tijd. Velen gingen uit van een trapsgewijs groeien in de heiliging, maar hiervan wilde Kohlbrügge niets weten. Kohlbrügge preekte voor het eenvoudige kerkvolk, dat het om het leven met God te doen is. 'Het arme en ellendige volk verstaat mijn preek' (Van Lonkhuyzen 1905:185). De heiliging komt niet voort uit een eigen ervaring of in een christelijke daad, maar uit een vergeten van zichzelf, die voortkomt uit de gemeenschap met Christus. 'In Zijn opstanding ligt een macht van genade tot alle Gode welbehagelijke wandel, en Zijn Geest houdt ons staande in de vrijheid. [...] In deze troost leef ik' (Kohlbrügge 1851).

Toen Kohlbrügge in 1833 tijdens een vakantie in het Wuppertal kwam, en daar zijn bekende preek uit Romeinen 7:14 hield, was zijn breuk met het Reveil in Nederland al geschied. In het gereformeerd-piëtistische Wuppertal werd hij geconfronteerd met de heiligmakingstheologie van de mysticus Tersteegen, de arts Collenbusch, de predikant Menken en anderen. Zij leerden dat de ethische volmaaktheid trapsgewijze kan worden bereikt. Zij stonden een heiligingsleer voor, waarbij de mens het heil aan zijn eigen bekering knoopt en dan verder zelf voortdurend kijkt naar de eigen vorderingen en zo de heiliging nastreeft. Kohlbrügge werd niet moe te verkondigen: Onze zekerheid van het heil halen wij nooit uit onze steeds onvolkomen bekering, maar daaruit, dat Christus zich geheel en al naar ons heeft toegewend. Hier is een wending van het subjectieve spreken naar het objectieve spreken. Van Zwinli en Calvijn neemt Kohlbrügge de oude, gereformeerde rangorde over: eerst Christus en Zijn Geest, en dan Zijn Woord:

Daar leed mijn gerechtigheid totale schipbreuk [...] daar, in mijn verlorenheid en radeloosheid is de Heer mij ontmoet en heeft mij gezegd: 'Zo als gij zijt, zo zijt u Mij heilig; daar niets van af, daar niets aan toe. [...] en nu is mijn enig heil in de hoogte en in de diepte: MET ONS GOD, en [...] al het andere acht ik, gelijk mijzelve, stof en nul'. ${ }^{8}$

7.De predikant Wilhelm Busch, van 1897-1906 predikant te Elberfeld bericht: 'Aber die Socialdemokratie im ganzen genommen, als Massenbewegung, bleibt eine Feindin des christlichen Glaubens', (in W. Busch 1926:81)

8.Aldus Kohlbrügge in een brief geschreven van 12 maart 1844 aan de heer Drost. Citaat in J. Künzli Zur Erinnerung an H.F. Kohlbrügge, Elberfeld 1875:16. De volledige brief in Bijlage B, 16-21 van J. van Lonkhuizen (1905). 
Romeinen 7:14 leerde hem: 'de wet is geestelijk zo is ook de zin 'ik ben vleselijk' een oordeel over hele mens. Niet 'voorzover ik vlees ben', maar ik 'ben vleselijk'. Mijn hele bestaan is zonde. Christus is onze gerechtigheid en onze heiligheid. Op deze wijze wordt Christus het thema van mijn leven en niet ik en ook niet mijn heiligmaking. ${ }^{9}$ Deze teneur van zijn prediking stond haaks op de 19e eeuwse mentaliteit van braafheid en vooruitgangsoptimisme.

Kohlbrügge keert tot Paulus terug, waar rechtvaardiging en heiligmaking twee aspecten zijn van dezelfde genade. Ellende, verlossing en dankbaarheid vormen geen biografische kalender, zij zijn de voortdurende driekwartsmaat van het geloof. Je kunt de genade niet achter je laten door je geheel op de heiliging te storten. De hoofdstukken 7 en 8 van de brief aan de Romeinen zijn voor Kohlbrügge één.

Wie in Christus is, moet dus ook bij Hem het leven zoeken en niet in zichzelf. Christus wil ons heilig maken en dit drijft ons tot de genade van Hem. Zo groeien, zonder mijn toedoen, de rijkste vruchten van de heiligmaking. 'Dit moet bij ons vaststaan, dat wij volstrekt in overeenstemming met de wet moeten zijn, en juist daarom hebben wij ons aan Christus, hebben wij aan Zijn genade vast te houden en zóó zullen wij door zijnen Geest, naar zijne belofte, wandelen aan zijne hand en naar zijnen raad, in een door Hem vervulde wet, zóó dat wij daarbij zondaars blijven en alleen zijne heiligmaking roemen'(Kohlbrügge 1851:161). ${ }^{10}$

Romeinen 7 schreef Paulus na de Damascus - ervaring. Kohlbrügge laat zien in zijn uitleg van Romeinen 7 dat hier de wedergeboren mens spreekt. Hij bevindt zich hier in de lijn van Augustinus via Luther, Zwingli, Calvijn tot Barth. Hoe dan ook: heiligmaking is bij Kohlbrügge geen zelfstandig thema, maar wordt alleen bij Christus ontdekt. Het is bij hem:

Eerst heilig zijn en dan heilig handelen en wandelen. Gij maakt uzelf niet heilig door handel en wandel; God heiligt $\mathrm{u}$ door verkiezing in Christus. Hij spreekt $u$ heilig en rein door Zijn Woord. Gelóóf dat gij heilig zijt en gij zult heilig wandelen (Kohlbrugge 1941:107-108). ${ }^{11}$

\section{'Christus extra nos'}

Of en in hoeverre Kohlbrügge en Krummacher de werkgevers en werknemers konden bereiken? In elk geval riepen zij niet op tot revolutie en het naar de barricaden gaan. Integendeel, Kohlbrügge stelt de vraag: 'Wat wil God van ons?' Dit: 'dat wij getrouw arbeiden, dus aan de tegenwoordige nieuwe begrippen niet het oor lenen. Het gaat hier om getrouwheid [...] Niet hetgeen men door allerlei listen en slechte praktijken heeft bijeengebracht, maar wat men met zijn handen in een

9.De preek uit Romeinen 7:14 is gehouden op 31 juli 1833 in Elberfeld. Volledig in het Nederlands in Twaalf Twaalftallen, dl.I en II, Amsterdam, 1910, 47/71.
Oorspronkelijke in H.F. Kohlbrügge, Drei Gastpredigten über Römer 7,14, Psalm 65:5 und Psalm 45: 14 / 16. Gehalten im Jahre 1833, Elberfeld, 4e Aufl. 1855.

10. Het is hier bij de behandeling van de Tien Geboden in de Catechismus, dat bij de vraag: 'Maar kunnen degenen die tot God bekeerd zijn, deze geboden volkomen houden?" (114e vraag), Kohloruge aangeet, dat deze vraag gericht is op hen die 列 geestelijke trappen tot volmaaktheid zou kunnen komen. Dit is volgens Kohlbrügge
(zie 214-216) 'eene duivelsche leer'.

11. Het is hier dat Kohlbrügge zich expliciet beroept op Calvijn!, a.w. 108. eerlijke weg heeft verkregen en verdiend, dat is Gods gave, en dat zegent God zodanig, dat men ook de noodruftige iets meedelen kan' (Kohlbrügge 1941:403). ${ }^{12}$ Laat hij daarmee toch de werknemers wat in de kou staan? Mensen die niet wisten hoe financieel rond te komen krijgen te horen: 'Op het geld, op een gulden, ja daarop ziet men. Maar Gods Woord, Gods zegen, het bloed van Jezus Christus, - wie ziet daarop? Tenzij dan dat hij door het water en het vuur gedreven is, en zó geleerd heeft het geld van harte te verachten en alleen op Gods zegen te zien'. [...] En wees niet afgunstig, als het uw broeder beter gaat dan $\mathrm{u}$, gun het hem van ganser harte' (Kohlbrügge 1941:406-407).

In een preek uit de bundel Aus tiefer Not over Psalm 118:26-27 houdt Kohlbrügge zijn gemeente voor dat wij in onze naaste, in de broeders en zusters het beeld van God ontmoeten. Zo'n ontmoeting is een 'proefsteen' voor ons om in de zorg voor de ander te laten merken wat de liefde van Gods ons waard is. Concreet is dan de inhoud van de zorg de vrijgevigheid en de troost! 'Zo handelt de liefde. Geboren in de afgrond, vraagt ze niet naar de afgrond, maar naar hen die in de afgrond zijn; men ziet op de Heere Jezus en waar men hoort klagen: "Wij zijn verloren! Wij zijn verdoemd en vervloekt!", daar moet je zeggen: "Wij zegenen u!"' (Kohlbrügge 1884:147) ${ }^{13}$ Duidelijk wordt, dat Kohlbrügge vooral de nadruk legt op geestelijke bijstand!

Bij Krummacher zijn de verdorvenheid van de mens, de genade van God, het verlossingswerk van Christus, en de wonderlijke leidingen van de Heilige Geest thema's die steeds terug keren. Hij stond negatief tegenover een heiligingsmethodisme (in Schütz 1972:183) ${ }^{14}$

De plaats van de christen in het gewone leven komt bij hem bijna niet ter sprake. Zowel G.D. Krummacher alsmede A. Bräm hebben een prekenbundel nagelaten over de reis van de Israëlieten van Egypte door de woestijn naar Kanaän (zie Krummacher 1879; Bräm 1859). Opmerkelijk is de insteek te zien: Gaat het bij Krummacher over de 'innere Führungen der Gläubigen', [innerlijke gidsen der gelovigen] daar vermeldt Bräm dat men deze preken 'auch auf das äussere Leben'[ook op het uiterlijke leven] moet toepassen. ${ }^{15}$

Kohlbrügge wijst heel sterk op het Christus extra nos [Christus buiten ons]. Dat was in de 19e eeuw een ongewoon geluid. Zijn realistische beschrijving hoe ambivalent religieuze gevoelens kunnen zijn, was in de tijd van de Romantiek hypermodern, maar tegelijkertijd maakte de beslistheid, waarmee deze gevoelens de rug werd toegekeerd en op Christus alleen gewezen werd, een ouderwetse indruk. Tegen het subjectivisme van de opwekking en haar heiligingsleer, benadrukte Kohlbrügge dat 'Gott unsere Seligkeit ausser uns

12.Kohlibügge in een preek - datum onbekend - uit de Heidelberger Catechismus uit de Achtste Gebod, Zondag 42.

13.Citaat, in eigen vertaling weergegeven, 147.

14.'Trocken und bizarr sind Krummachers Predigten, aber voll geistlicher Deutungen, sie sind unvermittelt und of reichlich derb, gewirkt haben sie durch ihre Entschiedenheit'.

15.Zie voor Krummacher het titelblad van Die Wanderungen en voor Bräm, E. Lohbeck, a.w. 162-165. 
und ohne uns in Christo hat dargestellt' [God onze zaligheid buiten ons en zonder ons in Christus heeft weergegeven] (in Barth 1946:583). Het is met de reformatorische principes onverenigbaar dat de mens aan het heilsproces een bijdrage kan leveren. ${ }^{16}$

De grote theologische vragen van zijn tijd - over de autoriteit van de Schrift, de gestalte van de kerk, de zin van de geschiedenis en de plaats van de gelovige in de samenleving, schijnen hen niet geraakt te hebben. Daar Kohlbrügge de Bijbel aan het woord wilde laten komen was hij volgens zijn vrouw Ursuline wat 'huiverig' ${ }^{\prime 7}$ voor praktische toepassingen. De tijdsanalyse werd met de heilsgeschiedenis in verbinding gebracht. In de veranderingen van die tijd zag men een nieuwe epoche in de geschiedenis van God met de mensen aanbreken. ${ }^{18}$ Het verwijt aan Kohlbrügge van de zijde van de liberalen was, dat het kenmerk van de humaniteit ontbrak: het ethisch appèl.

\section{Achtergronden}

Vanwaar deze zo uitgesproken prediking? Onder de christenen in het Wuppertal heerste lang niet altijd overeenstemming over de prediking. De textielfabrikant H.H. Grafe (1818-1869) (in Gäbler e.a.:2000:189), die tijdens zijn opleiding in Lyon in de Eglise Évangelique Libre had gekerkt, merkte op dat in Elberfeld het evangelie zijn smaak had verloren. Hij trad uit de kerk die hij verweet geen kerkelijke tucht en geen heiligingsernst te hebben! Het Wuppertal was sterk beïnvloed door het Piëtisme van Spener (1635-1705) en Francke (1663-1727). Spener had in zijn Pia Desideria ([1675] 1986) aangedrongen op een vernieuwing van het kerkelijk en geestelijk leven. Voor Francke's theologie is de accentuering van de bekering kenmerkend, als toegangspoort tot het christelijke leven (cf. Peschke 1964-1966). In de ontwikkeling van een piëtistische ethiek legde Francke het zwaartepunt op de eigen diaconale arbeid. Spener en Franke ging het om de applicatie van de boodschap in het dagelijkse leven. Vanuit deze 'hermeneutische horizon' benaderden zij het bijbels kerugma. Spener zag de rechtvaardiging in het perspectief van de heiliging. Vanuit dit perspectief belicht hij de betekenis van het geloof vooral vanuit het gezichtspunt van de geloofsvruchten. Kortom bij hem zien wij een verzet tegen het dualisme van leer en leven. Ook Francke accentueert, dat de genade geen 'müssige und sterile oder Fruchtlose Gnade / sondern immer thätig / geschäftlich / mittheilend / ausfliessend / fruchtbringend [...] wie ein springender Quell immer Wasser giebet' [Inactieve en steriele of vruchteloze genade / maar altijd bezig / zakelijk / mede helend / uitvloeiend / zoals

16.'Door de enge poort komen wij onzerzijds met geen traan, met geen zucht heen, en de poorten van de eeuwigheid zijn slechts de littekens in de handen van Christus, alleen hetgeen niets is komt er doorheen' (Kohlbrügge 1993:60) .

17.'Men heeft in Holland zoolang practicaal geloofd, dat men het geloove Christ daarbij verloren heeft'. [...] Er zijn geen bijvoegsels, toepassing of iets van dien aard. Alleen de naam onze Heeren worde genoemd in de kerke enDeze citaten in een brief van 12 december 1833. Aanwezig in de universiteits bibliotheek te Utrecht. Zie verder in J. Kommers, Ontwaakt, gij die slaapt!, a.w., 177, noot 810.

18.De opwekkingsprediker Ludwig Hofacker stelde dit in 1826: 'Das, nichts anderes, ist mein Amt; deswegen bin ich hier, ob ich euer etliche möchte für das Reich Gottes gewinnen und dem ewigen Feuer entreissen [...] Der Herr der Ernte hat mich hierher gestellt, um in der letzten betröbten Zeit Seelen für ihn zu werben, ob ich in Rielingshausen etliche für ihn gewinnen möchte ...' (in Knapp 1872:316). een wellende bron altijd water geeft]. ${ }^{19}$ Hij wilde Paulus en Jacobus verenigen. Er werd op toegezien niet in een ethisch perfektionisme te vervallen. Ook de wedergeborene doet zonden, maar deze zijn in hem niet heersend.

De notie van de rechtvaardiging van de goddeloze treedt zowel bij Spener als ook bij Francke wat op de achtergrond. $\mathrm{Bij}$ hen heeft de paulinische rechtvaardigingsleer een sterk ethiserend karakter. Volgens Francke gaat de Heilige Geest 'Stufen-weise' [stapsgewijze] te werk. ${ }^{20}$

Dat de heiligiging bij hen progressie vertoont komt door de vertaling van Luther van 1 Thessalonicenzen 5: 23: 'Er aber, der Gott des Friedens, heilige euch durch und durch. ...' [Hij echter, de God van de vrede, zal u door en door heiligen]. Het wenkende ideaal van het piëtisme in al zijn ontwikkelingsfasen bleef de nieuwe mens, de nieuwe schepping (2 Kor 5:17; Gal 6:15). Doorgaans kon men zich niet verenigen met de reformatorische exegese van Romeinen 7 . Het is niet te ontkennen, dat het gedachtenklimaat van het pietisme, juist met betrekking tot de heiliging, aanknopingspunten biedt voor het perfectionisme (Schmitt 1972:36v). Het maakte ernst met de inwoning en de werking van de Heilige Geest als het geheim van het nieuwe leven. Het piëtisme opent de ogen voor de rijkdom van Romeinen 8.

Breed was in die tijd de invloed merkbaar van de prediking van Lavater, Collenbusch, Menken (leerling van Collenbusch), Tersteegen en Jung-Stillung, die tussen 1780 en 1820 in de Wuppertaler opwekkingsbeweging diepe sporen trokken. ${ }^{21} \mathrm{Zij}$ waren gevormd door de spiritualiteit, leer en liturgie van de gereformeerde kerk, maar stukgelopen op haar orthodoxie. Maatstaf bij hen was niet het bijbelsobjectieve, maar het menselijk-verlichtende ingeving. Hier komen intellectualistische, maar ook antropocentrische momenten uit de Aufklärung [voorlichting] naar voren. De rechtvaardiging komt op de achtergrond en de heiliging van de vrome mens, die in zichtbare stappen volkomener wordt, op de voorgrond. Trapsgewijze komt de christen zo tot heiligheid. ${ }^{22}$

Het gereformeerde piëtisme in het Wuppertal ontwikkelde een min of meer eigen accent met de nadruk op de 'freie Gnade' [vrije genade]. De beweging met het perfectionistische heiligingsideaal heeft na 1840, mede door de prediking van Krummacher en Kohlbrügge, daar geen voet meer aan de grond gekregen. (in Krummacher 1935:230, Anm.1). ${ }^{23}$ Kohlbrügge belooft in zijn preken geen geestelijke successen, integendeel, de strijd zal van binnen en van buiten steeds 19.E. Peschke, a.w. I, 36-37.

20.E. Peschke, a.w. II, 110: 'Nach und nach, stufenweise, in einem unaufhörlichen Wachstum entdeckt Gott den Menschen die verborgenen Schätze der Weisheit'.

21. Caspar Lavater (1741-1801), Samuel Collenbusch (1724-1803), Gottfried Menken (1768-1831), Gerhard Tersteegen (1697-1769), Johann Heinrich Jung-Stilling (1740-1817).

22. Uitgebreid hierover Friedrich-Wilhelm Krummacher Gottfried Daniel Krummacher und die Niederrheinische Erweckungsbewegung zu Anfang des 19. Jahrhunderts, Walter Verlag, Berlin und Leipzig, 1935:37-61.

23.In 1825 schrijft Fr.W. Krummacher dit aan zijn ouders 'Menkens neue Predigten finden hier den alten Beifall nicht, Selbst seine Anhänger gestehen dass sie grossentheils zu trocken und zu unverständig seyn'. 
harder worden. Kohlbrügge en ook Krummacher, die zelf door het piëtisme zijn heengegaan, gaven aan de piëtisten een reformatorisch antwoord.

Ontbreekt dan bij hen het ethisch appèl? Heeft men inderdaad geen oog en oor gehad voor de kwesties die de samenleving raken? En hebben zij werkelijk geen aandacht geschonken aan de 'heiliging' in het leven van de gelovigen? Wanneer Kohlbrügge in 1835 aan zijn vriend Westendorp (1796-1863) schrijft, dat de gemeente moet letten op de vermaning van de apostel uit Hebreeën 12:14: 'Jaagt de heiligmaking na, zonder welke niemand God zien zal' om vervolgens het geheel te verinnerlijken, dan willen wij weten: Heeft de gemeente vanuit de verkondiging de consequenties gehoord van het Evangelie voor de praktijk van elke dag? ${ }^{24}$ Of was alles gericht op de 'bevinding' voor eigen hart en leven?

De grondtoon van de preken van Krummacher was ook dat de gelovige alles in Christus heeft. Het zwaartepunt ligt volgens hem in het handelen van God en niet in de menselijke ervaring. ${ }^{25}$ Men wordt niet steeds heiliger, maar zondiger in eigen oog. In de prekenbundel Jacobs Kampf und Sieg uit de jaren 1816-1817 worden op elke bladzijde voor bladzijde de mensen genodigd om te bouwen op de loutere erbarming van God en om af te zien van zichzelf. ${ }^{26} \mathrm{Bij}$ Krummacher is het zo, dat de ordo salutis, wedergeboorte, rechtvaardiging en heiliging concentrisch aaneensluiten. Op welke wijze God mensen in Zijn dienst gebruikt, is bij hem niet aan de orde. Zo kan hij antwoorden op de vraag:

Aber wo bleibt dan die Heiligung? Die bleibt bei demjenigen sicher nicht zurück, der da nur glaubt. Er braucht sich um nichts, als um das Glauben zu bekümmern; denn wenn er den nur fleissig übt, so wird die Heiligung von selber kommen. [Maar waar blijft dan de heiliging? Die blijft bij diegenen zeker niet achter, die alleen maar geloofd. Hij hoeft zoch om niets zorgen te maken als om het geloof, want wanneer hij maar ijverig oefend, dan zal de heiliging vanzelf komen.] (auteur eigen vertaling) $]^{27}$

\section{Geloven en niet zien}

'Een evangelische leraar van de heiliging in Christus', zo typeert Alfred de Quervain Kohlbrügge. ${ }^{28}$ Met de preek uit Romeinen 7:14 heeft Kohlbrügge de toon gezet in het Wuppertal. Deze preek wordt besloten met: 'Und habt ihr wahrlich Vergebung euer Sünden im Blute Christi, so sagt: "Ik bin heilig!" wenn ihr auch nichts als Unreinigkeit erblickt. Die Sache will geglaubt sein und nicht gesehen.' En hebt u echt vergeven uw

24.Zie in J.K. Vlasblom, Kohlbrugge en Westendorp. Een levenslange vriendschap, Boekencentrum, Zoetermeer 2005:86: 'Vraagt u naar heiligheid? Ik weet gewis/ Dat niemand in waarheid heilig is./ Dan een arme zondaar, die in de wonden/ Van zijnen Heiland heeft gevonden/ genade en vrêe'.

25.'Endlich bemerken wir noch, dass diese Süssigkeiten nicht wesentlich zum Ächten Christenthum gehören. Hören sie auf, so Hört darum die Gnade nicht mit auf'. In Die Wanderungen, a.w., IX: 65.

26.'Wir müssen wissen, dass Gott das Kreuz in alle seine Führungen genau verwebt hat, und das unter demselben der alte Mensch nach und nach verblutet', in Jacobs Kampf und Sieg, a.w., 14.

27.In G.D. Krummacher, Hauspostille, Meurs, 1836, Preek uit Romeinen 10, 4 'Christus ist des Gesetzes Ende, wer an den glaubt, der ist gerecht', 3-12, citaat 12.

28.In het voorwoord van Hermann Friedrich Kohlbrügge, Das siebte Kapitel des Römerbriefes, Heft 28 der Biblische Studien, Neukircher verlag, Mörs, 1960:6. 'Es ging ihm (Kohlbrügge, J.K.) allein um die Ehre Gottes, aufgerichtet in seinem
Christus: Christus des Menschen Heil und Frieden und darum auch des Menschen Christus: Chris zonden in het bloed van Christus, zegt 'ik ben heilg' ook als $\mathrm{u}$ niets als onreinheid gezien hebt. De zaak zak worden geloofd en niet gezien (Kohlbrügge 1855:20).Profetische en pastoraal geladen preken, waarbij het niet gaat om ons verborgen leven dat een schuilplaats is van vroom farizeïsme, maar waarbij het gaat om ons leven, dat in alle onaanschouwelijkheid in Christus verborgen is bij God. Vrome activistische christenen met hun zelfbewuste bevindelijkheid worden in de preken van Kohlbrügge en Krummacher doorlopend uit hun schuilhoeken opgejaagd en te kijk gezet als mensen die zich verschansen tegen de genade. Dit is zeker wáár, maar niet zonder heiliging, zou Kohlbrügge er aan toevoegen.

Wij zien het beeld voor ons van predikanten die pastoraal zijn ingegaan op de consequenties van Wet en Evangelie in het leven van de gemeente van Christus en van de gelovige enkeling. Anderzijds echter ziet men dat zij in de voorhanden zijnde preken, de grote vragen van hun tijd en van de maatschappij waar zij deel van uitmaakten, niet aan de orde hebben gesteld.

Kohlbrügge wilde voorkomen, dat de gelovigen de Wet van God, na ontvangen genade zelf ter hand zouden nemen in plaats van het te zoeken in Christus alleen. Voor Kohlbrügge is de stroom van diaconale zorg ontsproten aan wat de Bijbel noemt 'de diaconia van de verzoening'. In de echte diaconia gaat het Woord voorop. Zo wordt geloof geschapen en volgen de daden van dat geloof dat 'door de liefde werkt'. Bij hem gaat het om een theologische kwestie, waarbij de eigenlijke beslissingen vallen in de christologie. Kohlbrügge heeft het volk onderwezen in de betekenis van het Woord van God als een krachtig Woord dat tot daden leidt binnen de omheining van de heilige Wet. In dit kader spreekt Kohlbrügge werkgevers en werknemers aan.

Net zoals de rechtvaardiging is de heiliging een zaak van het geloof. De gelovigen zijn tot een heilig leven geroepen. Wie de Heilige Geest - door Kohlbrügge ook de 'Geest der heiliging' genoemd (zie Kohlbrügge 1940:21) - heeft, die is van Christus. 'Wie zijns is, heeft zijne vrucht, de vrucht dezes Geests - Zijne heiliging, en het Einde - het eeuwige Leven' (1940:166).

Kohlbrügge verbond alle zaligheid, alle leven, aan het 'blijven bij het Woord'. In dit kader kan de heiligmaking als daad van God ook niets anders zijn dan het trekken van de mens in gelovige aanvaarding van het Woord: 'U bent heilig in Christus, volmaakt in Hem.'

Christus is door Zijn voldoenend lijden, sterven en opstanding de 'nieuwe mens'. In Christus, ons voorgesteld in de Schriften, ligt onze gerechtigheid. Deel hebben aan die gerechtigheid is zaak van geloof. De heiliging nu is onlosmakelijk verbonden aan de rechtvaardiging. Alles is volbracht aan het kruis op Golgotha en met Christus zijn wij gedoopt in de dood, opdat gelijk Christus uit de doden is opgewekt tot heerlijkheid van de Vader, alzo ook wij in nieuwheid van het leven zouden wandelen (Rom 6:4). ${ }^{29}$

29.Zie hiervoor de preken die Kohlbrügge $(1894: 57,72)$ gehouden heeft over Romeinen 6. In H.F. Kohlbrügge Licht und Recht, Predigten, VII-XII, Kaufmann, Elberfeld. 
Buiten het Wuppertal was het Wichern ${ }^{30}$ die als predikant leer en leven als één zag. Vroomheid moest voor hem effectief zijn. Prediking mocht ook niet in moralisering vervallen, maar hij wist van de ethische eis die voor de zwakken, de armen en ellendigen van kracht was. Fel verzette hij zich tegen het communisme dat zich als een macht tegen de staat, volkskerk, familie en het godsgeloof afzette. Voor Marx ligt de toekomst bij het proletariaat, bij Wichern bij het kerkvolk en zijn gevestigde orde. ${ }^{31}$ Ook voor hem stond het 'redden' centraal, waarbij dit niet bestaat in een abstracte betrekking tot God, maar om het winnen van mensen voor een gezond christelijk samenleven. Diep geraakt was hij, zowel in Hamburg als later ook in Berlijn, over de geringe betrokkenheid van de bevolking bij de kerk en de sociale misstanden, vooral vanwege de openlijke prostitutie in de havenstad en het gebrek aan zondagsheiliging.

\section{Strijd tegen het subjectivisme}

Elke opwekkingsbeweging heeft het gevaar in zich de ervaarbareheiliging teoverschatten en derechtvaardigmaking als eenmalig gebeuren mis te verstaan. G.D. Krummacher wilde de gelovigen uit de kramp van de zelfvolmaking verlossen door hen steeds op het verlossingswerk van Jezus Christus te wijzen. Ondanks zijn strijd tegen de verabsolutering van het ' $\mathrm{ik}^{\prime}$ heeft Krummacher het individualistische begrippenschema niet doorbroken. Ook bij hem gaat het uiteindelijk om het heil van de afzonderlijke mensen en zijn in zijn preken de subjectieve heilsvragen de drijvende krachten. Dat God de mensen tot het geloof brengt en hen in Zijn dienst gebruikt komt bij hem niet aan de orde. En dat God een mens bevrijdt uit de kramp van de individuele vroomheid en de bevrijde mens gebruikt in Zijn missionaire dienst in de wereld, was voor Krummacher een brug te ver.

De strijd tegen het subjectivisme en de oproep tot een radicale onderwerping aan het Woord van God is in onze tijd, waarin zoveel nadruk ligt op de ervaring, opnieuw onderwerp van bezinning. De volle concentratie op Christus heeft er volgens Moltmann-Wendel toe geleid, dat de geschiedenis werd verdrongen en daarbij de existentiële vragen van de mens. Zij spreekt dan van 'Doketisierung der Geschichte' [Docetisering van de geschiedenis] (in Moltmann-Wendel 1957:17). Ontstaat er een dualisme tussen geest en natuur, zodat men de eigen geaardheid van de mens over het hoofd ziet? Willen wij de mens van onze tijd in aanraking brengen met het evangelie, dan moet hij weten wat hem drijft, draagt en troost in zijn verwarde alledaagse leven. Opvallend is dat in de donkere jaren voor de Tweede Wereldoorlog velen weer troost vonden in de existentiële preken van Kohlbrügge en Krummacher.

\section{Wel de gevolgen en niet de oorzaak}

Is toch de heiliging bij Kohlbrügge zijn heimelijk hoofdthema? Hij formuleerde weliswaar de antwoorden op

30.Johann Heinrich Wichern (1808-1881).

31.'Es ist der dringende, unabweisbare, heutige Beruf der Kirche, sich des Proletariats in seinem tiefsten Grunde anzunehmen', (in Wichern 1848:141). de heiligingsvragen anders, namelijk vanuit de traditie waar hij vandaan kwam, preciezer gezegd: bij de genade vandaan.

De kracht van zijn homiletisch werk is de bijbelse exegese, waarbij inhoud en vorm zeer nauw aansluiten bij het originele spraakgebruik van de Bijbel. Heiliging draagt volgens Paulus een eschatologisch karakter, omdat de Geest, die haar bewerkt, de gave van de eindtijd is (zie Versteeg 1969). De indicatieven bij Paulus blijven de imperatieven insluiten.

Het 'Niet dat ik het al verkregen heb of al volmaakt ben, maar ik jaag ernaar om het ook te grijpen'(Fil 3:12), kreeg bij hem nieuwe klank. Paulus tekent het christelijke leven als strijd, als militia christiana (Gal 5:13-26). Ik ben nog niet volmaakt zegt Paulus, maar ik jaag naar het doel. Nooit hier volkomen. Christus en Zijn verlossingswerk, dat is volkomen! Op soms bijna hymnische wijze kan Kohlbrügge dit verkondigen.

Heiliging, heiliger worden? De weg loopt omgekeerd. De gelovige wordt niet heiliger, maar steeds zondiger in eigen oog. Prediking die er op gericht was het wankelend hart te hechten aan Hem, Die de Getrouwe is. Ons geloof, ons vasthouden, ons blijven bij het Woord is geen prestatie en product van de heiligen, maar is de onverdiende gratie die naar hen toekomt uit Hem, Die de hele zaligheid bewerkt. De sterke aandacht bij Kohlbrügge in de preken over de opstanding: Christus is opgestaan en heeft voor ons de levendmakende Geest verworven, is een stuk theologie dat onder de ethici wat in de vergetelheid geraakte (cf. Kohlbrügge 1941:107).

Wij nemen Kohlbrügge in bescherming tegen de kritiek dat hij de heiliging verwaarloosde, anders gezegd: de christelijke ethiek zou bij hem te kort komen. Wel zijn aan deze wat tijdloze preken grenzen gesteld. Het gaat om het individualisme dat overal naar voren komt. De ethiek van het individu staat meer prominent op de voorgrond dan de sociaale ethiek. Maar het is niet zo, dat men in het Wuppertal geen sociale verantwoordelijkheid heeft gehad. De vele mooie voorbeelden van praktisch hulpverlening weerleggen dat. In Bethel bij Bielefeld waren de inrichtingen van Bodelschwing, deze leefden veelal van de gaven uit het Wuppertal; en denk ook aan het Diakonie Systeem in Elberfeld zelf, op initiatief van de Reformierte Gemeinde. Persoonlijk hebben Krummacher en Kohlbrügge heel veel mensen praktisch geholpen. Maar zij bleven kinderen van de 19e eeuw. Thema's als: Christus en mij; Christus en mijn rechtvaardigmaking; Christus en mijn heiligmaking, worden: Christus in mijn plaats; Christus voor mij, alles Christus. Zij hebben minder gevraagd naar Christus en Zijn kerk; Christus als Heere van de toekomst en hoop voor de wereld.

In het Wuppertal werden wel de gevolgen, maar niet de oorzaken van de sociale ellende bestreden. De ellendige toestanden waaronder kinderen moesten werken, en die Friedrich Engels heeft beschreven in zijn dagboeken, hebben in de preken van Krummacher, Kohlbrügge en vele anderen 
uit die tijd geen echo gevonden. Het lijkt wel of zij veel beter thuis waren in de zaken van het hemels Jeruzalem, dan in wat er gebeurde in de straten en stegen van Elberfeld. Wij vragen ons af, hoe predikers, die zo zeer het Oude Testament hebben bestudeerd en bepreekt, daarover niet hun roep hebben laten horen, en daar in Elberfeld de Wet van God en de toorn oproepende toestanden van de profeten, niet hebben weersproken.

De gidsfunctie die de predikers hierin zouden moeten hebben is niet tot volle bloei gekomen (zie Krummacher 1935:266). Ze liepen in hun preken maar één paadje af en hebben niet de volle scopus van Paulus in het oog gehad. Zo zij al antwoorden gaven, dan waren die uitsluitend gericht op het diaconaat met alle daarbij komende edele motieven en goede bedoelingen, maar tegelijk ook met haar grenzen. In de concrete levensverhoudingen reduceerden zij het breken met de macht van de zonde meestal tot de individuele ascetische moraal. Typisch piëtisch wezen zij de onschuldige vreugden in het leven af en een wettische onderstroom bleef aanwezig in de preken. Het preken tegen brandewijn, dronkenschap, de verpaupering, de prostitutie en de uitbuiting van de werknemers door fabrieksdirekteuren, voorkwam niet dat dit alles toch het leven bleef bepalen, omdat deze verkondiging theologisch te 'kortademig' was.

\section{Rijk in God}

Wilhelm Busch trof 25 jaar na de dood van Kohlbrügge, in het Wuppertal een 'levendige gemeente' aan, maar ook hij zag nog velen 'aan de schaduwkant van het leven':

Dag in dag uit zonder een vakantie de zieldodendede arbeid in de fabriek, slecht betaald, met de nek aangekeken volk, door voortdurende ophitsing verbitterd, innerlijk verarmt, terwijl een doorgaans armzalig blad van de partij hun enige geestelijke voedsel was. (Busch 1926:103,105, [citaat weergegeven in eigen vertaling]).

Hier greep het socialisme breed om zich heen en werd het Wuppertal de bakermat van de Nationaal Socialistische Beweging en vormde mede daardoor een platform en voedingsbodem voor het Nazi-regime tussen 1930-1945.

Hier trof de kerk de 'vermoeiden en beladenen', die een hemelse toekomst in de verkondiging voor ogen werd gesteld, maar zelf geen direkt antwoord had vanuit de verkondiging op de voortdurende sociale nood.

De predikers waren kinderen van hun tijd en dat heeft zeker hun prediking gekleurd. Anderen hebben meer de zonden en de sociale misstanden benoemd en aangepakt in de verkondiging. De Innere Mission van Wichern werd door Krummacher en Kohlbrügge ook gedaan, maar dan in de zin van: Innere Mission [binnenste missie] in eigen hart. Maar voor Wichern was prediking, zending en evangelisatie als een vogel, die geen kooi kan verdragen.

Als goed piëtistisch zochten Krummacher en Kohlbrügge de oorzaak van de misstanden in de eerste plaats in de mensen en niet in de structuren. In de preken, zo hebben wij gezien, komt herhaaldelijk de strijd tegen wat in de Bijbel heet 'de wortel van alle kwaad' en 'afgoderij'; namelijk de hebzucht. De mensonwaardige levensomstandigheden van een groot deel van de bevolking komen uit dezelfde wortel voort. Maar men bleef in het conservatieve schema, te nationalistisch en te tijdgebonden.

Het is niet direkt tot een getuigenis gekomen, maar is bij het redden gebleven. Het werk was curatief werk, niet preventief. In de hoogspanning van het geloof kwam het 'gewone' leven van huwelijk, gezin, beroep, werk en politiek makkelijk in de schaduw (zie De Quervain 1946) . ${ }^{32}$ Volgens Beyreuther is het piëtisme de laatste grote en echte, 'zeugenfreudige Bewegung der Kirchengeschichte' geweest, die de protentantse kerk in beweging heeft kunnen brengen (in Beyrether 1980:8). Dat de Wuppertaler predikers binnen deze beweging hun partij krachtig hebben meegespeeld, is ons niet ontgaan; beweging bewaart de kerk voor routine en conventie. Maar ook is ons niet ontgaan, dat deze predikers niet de exclusieve hermeneutische sleutel hadden voor het verstaan van heel het evangelie.

\section{Conclusie}

Indirect is hier de vraag aan de orde geweest in hoeverre de verkondiging in het Wuppertal van invloed is geweest op de openlijke doorwerking in het concrete leven van alle dag in Elberfeld. Het preken gebeurt niet in een vacuüm. De prediking kwam tot gewone mensen die vol in het leven stonden.

Woord verkondiging omspant in alle dimensies de wereld en de werkelijkheid, en ook de mens die daarin leeft, zien wij in het licht van de gekruisigde en opgestane Christus. Jezus is Here, ook van de wereld en van ons leven. De verkondiging in het Wuppertal was zo sterk op het innerlijk van de mens gericht, dat ze de betrekking op de wereld verloor. Voor de gelovigen is 'wereld' zo geworden tot een synoniem voor de niet-wedergeboren, natuurlijke, niet-geheiligde toestand van de mens. Voor Kohlbrügge wordt het leven hier op aarde als een leven in een 'Jammerthal' (jammerdal), omdat de christen telkens door 'de dwaze wereld' belaagd wordt. In het Wuppertal hechtte men sterk aan het 'Zo spreekt de Here', maar de concrete situatie werd niet geplaatst in het licht van de Schrift, en zodoende is deze prediking niet altijd de volle weerslag van wat Bijbelse verkondiging wil zijn. De profeten in het Oude Testament hebben wantoestanden in de samenleving niet gesanctioneerd. Uit vrees voor al te veel menselijk activisme is het ethisch element, zo niet geheel genegeerd, dan wel sterk begrensd. Voor hen was het God alleen die de mens leidt uit zijn geestelijke en sociale onmacht, zodra de mens Hem in Zijn soevereiniteit erkent. De heilige is die mens die zich voor God verootmoedigt. Vandaar dat in het Wuppertal breeduit gesproken werd over de zwakheid van de mens, maar nog dringender over de barmhartigheid van God in Christus Jezus.

32.Wij zien dat 100 jaar later, door een van de predikanten van de Nierländisch Reformierte Gemeinde, Alfred de Quervain, ethiek op gemeenteavonden werd gedoceerd waarbij heel concreet de heiliging en Gods geboden werden behandeld voor het gewone leven. 
In onze hoog geindustrialiseerde samenleving staan arbeidsomstandigheden in veel landen onder druk en vindt uitbuiting, kinderarbeid, onrust vanwege werkeloosheid etc. nog steeds - ook in zogenaamde christelijke landen - op grote schaal plaats. Het heldere getuigenis van het Evangelie dient door de christelijke kerken in de samenleving uitgedragen en gehoord te worden. Het luisteren naar, en het doen van de inzettingen van God is tot zegen voor de christelijke gemeente en voor de samenleving.

\section{Erkenningen \\ Tegenstrijdige belangen}

De auteur verklaart geen financiële of persoonlijke belangen te hebben die hem ongepast kunnen hebben beïnvloed bij het schrijven van dit artikel.

\section{Literatuurverwijzingen}

Barth, K., 1946, Die protestantische Theologie im 19, Jahrhundert, Theol. Verlag, Zürich.

Barth, K., 1981, Die protestantische Theologie im 19, Jahrhundert, 5e dr., Theol. Verlag, Zürich.

Benrath, G.A., 2000, 'Die Erweckung innerhalb der deutschen Landeskirchen', in U.Gäbler e.a. (Hrsg.), Geschichte des Pietismus, deel III, bl. 184-271, Vandenhoeck \& Ruprecht, Göttingen.

Beyreuther, E., 1980, Frömmigkeit und Theologie, Olms Verlag, Hildesheim.

Bräm, A., 1859, Israels Wanderung von Gosen bis zum Sinai, Publisher ,Elberfeld.

Busch, W., 1926, Pfarrer dr. Wilhelm Busch, Sein Leben und Wirken, Verlag Überreich, Hamburg.

De Quervain, A., 1946, Die Heiligung, Ethik, 1e Teil, 2e Aufl., Evang, Zurich.

Gäbler, U., 1991, Auferstehungszeit', Erweckungsprediger des 19, Jahrhunderts, Verlag C.H. Beck, München

Gäbler, U., 2000, e.a., Der Pietismus im neunzehnten und zwanzigsten Jahrhundert Band III/ Geschichte des Pietismus, Vandenhoeck \& Ruprecht, Göttingen.

Grafe, H., 1965, Die volkstümliche Predigt des Ludwig Harms, Vandenhoeck \& Rupprecht, Göttingen.

Greshat, M., 1980, Das Zeitalter der Industrieëllen Revolution: Das Christentum von der Moderne, n.p., Stuttgart.

Herberts, H., z.j., Alles ist Kirche und Handel ... Wissenschaft und Gesellschaft des Wuppertals im Vormärz und in der Revolution 1848/49, n.p., Wuppertal.

Hermand, J., 1967, Der Deutsche Vormärz, Texte und Dokumente, Publisher, Stuttgart. Knapp, A., 1872, Leben von Ludwig Hofacker, 4e ed., n.p., Heidelberg.
Kohlbrügge, F., 1840, Het zevende Kapittel van den Brief van Paulus aan de Romeinen, uit het hoogduits vertaald door E. van Heumen, n.p., Amsterdam.

Kohlbrügge, H.F., 1851, Vragen en Antwoorden tot opheldering en bevestiging van den Heidelberschen Catechismus, Uitg. Melder, Utrecht.

Kohlbrügge, H.F., 1855, Drei Gastpredigten, 3e Aufl., Verlag Niederländisch Reformierten Gemeine, Elberfeld.

Kohlbrügge, H.F., 1884, 'Aus tiefer Not', Vierzehn Predigten über den hundertachtzehnten Psalm, Verlag Niederländisch Reform-Gemeine, Elberfeld.

Kohlbrügge, H.F., 1887/1894, Licht und Recht, Predigten, Heft I-XII, 2 delen, Kaufmann, Elberfeld.

Kohlbrügge, H.F., 1903, Die Lehre des Heils, Verlag Niederländische Reformierte Gemeine, Elberfeld.

Kohlbrügge, H.F., 1941, De eenvoudige Heidelberger, Callenbach, Nijkerk.

Kohlbrügge, H.F., 1960, Das siebte Kapitel des Römerbriefes, Heft 28 der Biblische Studien, Neukircher verlag, Mörs.

Kohlbrügge, H.F., 1993, O God, wees mij genadig, De Groot, Goudriaan-Kampen.

Kommers, J., 2005, 'Ontwaakt, Gij die slaapt!', Uitg. Groen, Heerenveen.

Kreck, W., 1936, Die Lehre von der Heiligung bei H.F. Kohlbrügge, Kaiser Verlag, München.

Kreck, W., 1982, Reformierte Kirchenzeitung, 122 Jg., 15 Sept. 234.

G.D. Krummacher, 1836, Preek uit Romeinen 10:4 'Christus ist des Gesetzes Ende, wer an den glaubt, der ist gerecht', 3-12, citaat 12, Hauspostille, Meurs.

Krummacher, G.D., 1879, Die Wanderungen Israels durch die Wüste nach Kanaan, Hassel Verlag, Köln.

Krummacher, G.D., 1936, Wahtheit zur Gottseligkeit, Eine Sammlung Predigten für alle Sonn-und Festage, Hauspostille, Meurs.

Krummacher, Fr.W., 1935, Gottfried Daniel Krummacher und die niederrheinische Erweckungs-bewegung zu Anfang des 19, Jahrhunderts, Verlag W. de Gruyter \& Co., Berlin-Leipzig.

Kuccynski, J., 1967, Das Entstehen der Arbeitersklasse, n.p., München.

Lohbeck, E., 1989, Andreas Bräm - ein Wegbereiter der Diakonie im Rheinland und Gründer des Neukirchener Erziehungsvereins, 94, SVRK, Neukirchener Verlag, Neukirchen-Vluyn.

Moltmann-Wendel, E., 1957, Theologie und Kirche bei Hermann Friedrich Kohlbrügge, Chr. Kaiser Verlag, München.

Peschke, E., 1964/1966, Studien zur Theologie August Hermann Francke's, I en II, n.p., Berlin.

Przybylski, L., 1977, Die Kirche am Kolk, Die Geschichte der evangelisch-lutherischen Gemeinde Elberfeld, Brockhaus Verlag, Wuppertal.

Schütz, W., 1972, Geschichte der christlichen Predigt, Walter de Gruyter, Berlin/New York.

Schmitt, 1972, Pietismus, n.p., Stuttgart.

Tholuck, F.A., 1823, Die Lehre von der Sünde und vom Versöhner, n.p., Hamburg.

Van Lonkhuyzen, J., 1905, Hermann Friedrich Kohlbrügge en zijn prediking, VU Amsterdam, Wageningen.

Vlasblom, J.K., 2005, Kohlbrugge en Westendorp, Een levenslange vriendschap, Boekencentrum, Zoetermeer.

Versteeg, J.P., 1969, Het heden van de toekomst, n.p., Kampen.

Wichern, J.H., 1848, Die Revolution und die Innere Mission, Sammliche Werke, n.p., n.p. 